\title{
Oral history and historical education in Poland. Possibilities and application
}

\section{Introductory Notes}

Every time I read or hear in the media about young Poles' successes in international knowledge competitions I am fulfilled with joy. It is caused by the fact or, despite the fact that these competitions concern topics that I do not deal with on every day basis, i.e. the exact sciences, technology, life sciences. The spirit of creative activity prevails over ordinary reproductive recalling of knowledge already learned throughout the cumulative learning process. Young people fascinated by chemistry, physics, IT or biology, encouraged by their mentors to search actively for possible solutions to certain problems start discovering, as though immersed in creative frenzy, new ways to achieve what prior generations of researchers only dreamt of. Their fresh ideas reaching beyond rigid frames of school subjects (and these ideas require knowledge not only on biology, chemistry or technology but also biochemistry and biotechnology etc.) tend to be so innovative that they find application in numerous branches of industry and science. What is more, winners of such competitions are warmly welcomed by the best universities in the world. What concerns me however is the question: why is it that we often hear about young people winning competitions in widely understood science and barely never about winners of competitions concerning the opposite field of interest i.e. humanities, in particular in history? Both 
disciplines of science are present throughout the entire education process at school. Are there no international humanities competitions? In my opinion, the problem lies elsewhere and is rooted in the education process at school. Both kinds of competitions require possessing a certain knowledge. The difference is in the starting point of this knowledge. In exact science competitions knowledge is a crucial basis for certain practical actions, experiments etc. (I need to know the basics of mechanics to build a remote control robot model) whereas competitions in the humanities require "knowledge of..." itself, to know as many facts about something or someone as possible (I've read everything about the Napoleonic Wars so I fulfilled my aim). Creativity and generation is reduced, there is no way of discovering something new, unknown to the rest of the world. It reflects the quality of our education system. That leads to my question that I would like to ask from the perspective of a history methodologist: is it possible to teach history in a more creative way that will encourage pupils to take part in the knowledge generation process instead of only listening? In my opinion it is possible. But if so, why there are so many people unable to notice that? Does it mean that people outside the educational system who say that "teachers can't teach" are right? I would not say so. Again, the problem lies elsewhere, much deeper.

Later in this paper I would like to focus on the presence of oral history in teaching history at school as a tool for teachers. In my opinion, this presence is specific and by saying it I mean running away from traditionally understood history and its abundance in our life. As far as education is concerned, running away involves elements that teach us understanding and empathy towards topics existing outside of the official historical discourse. Oral history is one of these elements. It is oral history that enables pupils to discover their own history and makes them more sensitive to social ties and relations between the generations. I would like to illustrate ideas mentioned above with chosen examples of applying or possibility of applying oral history in teaching history in Poland and simultaneously indicate how many possibilities there are yet to be used ${ }^{1}$.

In this paper I will refer only to a couple of examples of oral history in the entire education process in Poland, for more detailed explanation and examples see: I. Lewandowska, Oral history we wspótczesnej Polsce - badania, projekty, stowarzyszenia, “Wrocławski Rocznik Historii Mówionej”, Vol. 1 (2011), p. 81-103. 
Before proceeding to enumerate reasons why oral history is not present in education process at $\mathrm{school}^{2}$, I would like to focus on condition of history in Poland as a part of our education and culture and its entanglement in politics. If we are unaware of these limitations, the presence of oral history in education process loses its importance. In order to illustrate issues mentioned above I would like to refer to two leaders of methodological thought in Poland, that is: Wojciech Wrzosek and Jan Pomorski.

As Wrzosek reasonably indicates in his publication Czy historia ma przyszłość? (Does the history have a future?), it would be hard to imagine any of the existing societies functioning without history. As for now, we don't know what kind of changes in our perception and understanding of civilisation would make us think that history is no longer needed. And that is all as far as positive attitude towards knowledge of the past is concerned. In most cases, people need history to have the other dimension described by Wrzosek:

Usually when people are asked if the history is needed, those who answer that it loses its importance refer not really to history but to information about events from the past, they really mean spectacular facts from the history of their nation, country, that their country and its neighbours took part in. Do we need this kind of information of the past? Maybe, but we can live happily without them. Contemporary people who don't know the exact date of The Battle of Racławice or Peace of Westphalia, who don't remember the date of the first Polish free election, Congress of Vienna or Peace of Thorn are not worse IT specialists, ecologists, engineers or physicians because of the lack of this knowledge. Not possessing this knowledge on history understood as a collection of archival facts does not make their life harder in any way. [...] So, if we perceive history as in the example presented above, the answer to the question "do we need to possess knowledge of the past?" is no. If our perception of the history is limited to this kind of thinking, the answer is clear-cut: we do not need history at all. In my opinion, huge number of people perceive history this way. It is caused both by the factual and event-based approach to teaching and learning history ${ }^{3}$.

2 Here I'm focused mainly on methodologies and historiography concerning history and theory and practice of oral history. I do not feel competent to discuss methods of teaching history and education process on its own.

3 W. Wrzosek, Czy historia ma przyszłość?, [in:] Gra i konieczność. Zbiór rozpraw $z$ historii historiografii i filozofii historii, ed. by G. A. Dominiak, J. Ostoja-Zagórski, W. Wrzosek, Bydgoszcz 2005, p. 11-12. 
Let's think about our school education referred to as factual and methods of verifying knowledge gained this way. In most cases the exam involved answering following questions - What? Who? Where? and When? So, according to this method, sufficient knowledge on e.g. the Prussian Homage means knowing that: Zygmunt I the Old with Albrecht Hohenzollern, on the April 10, 1525 in Kraków market square. Probably the exact date would be an extra information. What would happen if we asked someone not professionally connected with history to prepare at least 10-sentence narrative about this event explaining its significance? I suppose that no one would be able or willing to do that. It is because our approach towards understanding the past is mainly factual and event-based. No one reflects on the basic question i.e. why do we need history, what do we need it for and why do we learn it at school? By agreeing with Wrzosek that we need history only to be able to understand, give meaning and domesticate ${ }^{4}$ the present, it seems obvious that we are seeking escape from factual and event-based way of understanding history in education process.

The escape from specific understanding and treatment of history has also been discussed by Pomorski. Here, an exit point is a connection of knowledge of the past and politics, which seems inevitable. Now it is time to ask if this relation may be perceived from the perspective of the social experiencing of history. The answer is obvious and positive. It has been done this way before in the USA, where, referring to relation between history of the victors vs. the history of the defeated, we could observe many takeovers and revolutions in the past decades. The defeated, who were unable to speak their minds before are now becoming visible and bound to make history by changing old standards of political correctness. Innovative, non-standard methods of teaching history are both an important part and the driving force of these changes. The situation in Europe is totally different, especially in its Eastern Central part that was strongly influenced by the Soviet Union. According to Pomorski:

Europe that went through two world wars and two kinds of totalitarianism in the $20^{\text {th }}$ century, started to fear living with "too much history", the past that separates and envenoms nations [...]. Overcoming the history took the form of escaping from it. Escaping from it in two ways ${ }^{5}$.

4 Ibidem, p. 13.

5 J. Pomorski, Ucieczka od historii jako element poprawności politycznej - tezy, [in:] Pamięć i polityka historyczna. Doświadczenia Polski i jej sassiadów, ed. by S. M. Nowinowski, J. Pomorski, R. Stobiecki, Łódź 2008, p. 112. 
The first one, less connected with this paper, is a kind of exposing memory to give it an ethic dimension. According to Pomorski, it makes it function as a "cultural religiousness". Second way of escaping from history which is monumental and burdened with totalitarianism is pursued at schools where, on one hand, we deal with moving away from traditional way of teaching history and, on the other hand, introducing elements that teach pupils understanding and empathy towards topics that were kept outside the official historical discourse for years.

Contemporary condition of the history, especially in schools, is poor because it needs to deal with two main issues that, in my opinion, may be overcome by introducing oral history.

The issue with oral history The legitimacy of oral history in education process at school results from three different ways of perceiving this research discipline. The first one sees oral history as a research method but also as an independent discipline or social movement, paradoxically - if we took into consideration its complicated adaptation process at universities - it is the essence of what may be referred to as "practising history". In the second one, history is equated with a unique sphere in which we observe interplay of key methodological problems concerning historical research such as the issue of truth, the opposition of subjectivity/objectivity, the position of a historian in constructing/reconstructing the past reality, the function of narratives and historical sources. In the third one, oral history is seen as a method to break rigid academic structures, which means that history as a form of practising science may be both an academic discipline and a social undertaking at the same time. This approach perceives oral history as a many-sided network connecting the historian, the witness to history and the audience - recipients as a specific fusion of the past, the present and the future based on human memories and experiences. This enables us to locate history closer to the people. All those ways of perceiving oral history are meant to prove that it is a fully-fledged research practice supporting history as a science field.

This approach to oral history makes it a way to escape both from the method of teaching history based only on archival facts and events and the abundance of martyrdom in our history. It is because this approach promotes inter-generational and social creation of collective identity based on remembering what we feel connected with the most. Such opinions result from many years of experience in teaching history with the use of oral history. As Marta Kubiszyn explains: 
As far as teaching practice is concerned, shaping attitudes targeted to realise the values mentioned above requires, among other things, moving away from standard teaching methods and introducing individual innovative methods developing imagination and critical thinking, teaching pupils how to communicate and work in group but also referring to widely understood sociocultural local heritage. [...] These aims and tasks may be reached within local education, also called community education, understood as a method of organizing the life of local community so it can realize certain socio-educational tasks and as a tool to introduce social changes. Referring to oral history as this kind of education method is not only a great way to inform people about their environment and developing closer ties between generations and support activities promoting protection of historical and cultural identity but it can also support development of democracy and civil society through activation of local communities and strengthening identity of individuals ${ }^{6}$.

On the one hand, the author refers here both to collective and individual memory as a source of knowledge of the past presented from the perspective of ordinary people with whom we feel more connected and we are able to domesticate our here and now better. On the other hand, we learn to understand and have empathy towards these aspects of the past that were marginalised, supplanted by the abundance of martyrdom in our history. Dobrochna Kałwa perceives this process similarly:

The dialogue between a professional researcher and a witnesses to history makes us aware how many meanings and functions history may have - experienced, told and reproduced in inter-generational dialogue. It is (or may become someday) an educational and civil activity as it enables people to build collective identity, solve conflicts and activate the society and these are only a few examples. This current combining civil society and education played an important role in creating - in opposition to the official historiography - perception of the modern history and building post-communist collective memory. [...] Oral history proved to be a quite interesting tool for social activation in local communities as it develops

6 M. Kubiszyn, Edukacyjne implikacje projektu dokumentacyjnego $i$ animacyjnego w środowisku lokalnym - między teorią a praktyką. "Historia Mówiona Miasta Lublina” Ośrodka Brama Grodzka - Teatr NN, "Wrocławski Rocznik Historii Mówionej", Vol. 2 (2012), p. 103. 

is a great way to teach history ${ }^{7}$.

It may seem that the remarks of this kind result from the importance and constant presence of oral history in Polish educational system. Unfortunately, this is not the case. Its presence is only a fraction of what it could be. I will only mention a few observations which concern the attitude to oral history of those who could use it in their educational activity. However, I will not mention a complex problem of negative attitude towards this research method adopted by a large group of historians-academics ${ }^{8}$.

7 D. Kałwa, Historia mówiona w krajach postkomunistycznych. Rekonesans, "Kultura i Historia”, Vol. 18 (2010), http://kulturaihistoria.umcs.lublin.pl/archives/1887 (accessed March 20, 2016).

8 This is not my intention to address this problem in the main text, but in my opinion this negative attitude is caused mainly by the nature of the oral source as a historical source. Therefore, consider important to shortly present the two main stands on this issue.

The first one concerns German individualistic historicism. Its postulates in relation to general history were clearly expounded by Leopold von Ranke, who listed among others the pure admiration for truth that is the willingness to get to know the past, thorough, in-depth and, what is important, source studies, universal interest in pure cognition, examining the causality, objectivity and the awareness of totality of historical phenomena. Fulfilling those postulates which are elements of a research method of written sources, was to be helpful in establishing the facts from the past and presenting them to the reader. According to that a historian was to become a kind of impartial observer, calculating discoverer of the truth who would be able to study the past breaking away from his time (Cf. R. Stobiecki, Historiografia na przełomie XIX i XX wieku. Krajobraz po bitwie, "Biuletyn Polskiego Towarzystwa Historycznego", November 2005, p. 11-22). The cult of a written source also played an important role. Its definition was so narrowed down that it did not encompass not only oral sources but also earlier historiographical works. As Andrzej Feliks Grabski rightly noticed: "Ranke's criticism of modern historiography led him to the conclusion that for scientific, critical history historiographical sources are much less valuable as a historical source than archival sources, especially those in the form of documents" (A. F. Grabski, Dzieje historiografii, Poznań 2003, p. 469). The role of a historian understood in this way was not assessing the past and leading the way to the next generations but revealing the truth about the past.

Marceli Handelsman held a similar view on understanding a historical source. Although in his classification he took into consideration the oral tradition, he only considered historical documents as the proper historical sources (see: M. Handelsman, Historyka, Warszawa 1928, p. 45; G. Labuda, Próba nowej systematyki $i$ nowej interpretacji źródeł historycznych, "Studia Źródłoznawcze”, Vol. 1 (1957), 
p. 3-52). However, other historians hold a completely opposite view, for instance Krystyna Kersten who in her reference to the history of 1960 s emphasized the need to generate sources by historians, understood by her as oral sources. In her view, using eye-witness accounts, including oral accounts, in historical research is neither new nor characteristic of modern times. According to her a historian dealing with the recent history, called by Kersten "life history", cannot avoid in his or her work generating oral sources which entails the need to develop new methods of critical analysis of these accounts (see: K. Kersten, Historyk - twórcq źródeł, "Kwartalnik Historyczny", Vol. 2 (1971), p. 313-330). This kind of mistake was made by modern historians of our region which was mentioned in the above cited text by Dobrochna Kałwa, who consider oral accounts as equal to typographical sources through employing the same research method to both kinds of sources. This procedure together with scepticism about oral accounts and prudence in employing them result from the need to faithfully reconstruct historical reality which Kałwa, following Sorin Antohi, calls the dominance of paleo-positivistic paradigm (see: D. Kałwa, op. cit.). In accordance with Kersten's postulate, Andrzej Paczkowski also highlights the obviousness of oral accounts being present in recent history research. However, he locates their source in a press interview and calls oral history an academic subdiscipline which is a "history" only by name because it is more frequently present in sociology, anthropology or social psychology and not in history as a practice aiming at learning about the past and understanding it (see: A. Paczkowski, O osobliwościach badań nad historiq najnowsza, [in:] Historyk wobec źródeł. Historiografia klasyczna $i$ nowe propozycje metodologiczne, ed. by J. Kolbuszewska, R. Stobiecki, Łódź 2010, p. 163-171).

In my opinion, all those problems and nuances have their roots in allowing latitude in understanding, defining and classifying oral history, even though certain attempts have been made to clarify those issues (see: M. Kierzkowski, Historia mówiona próba definicji pojęcia, "Wrocławski Rocznik Historii Mówionej", Vol. 4 (2014), p. 5-20). The climax of the discussion on understanding and using oral history by Polish researchers of the recent history was reached after the publication in 2009 of Paweł Zyzak's book entitled Lech Watęsa. Idea i historia. Biografia polityczna legendarnego przywódcy "Solidarności" do 1988 roku. Historians, journalists and politicians took part in this discussion. Leaving aside Paweł Zyzak's object of studies itself, each participant of the discussion referred to oral history in relation to that object. It happened because Zyzak, from the very beginning, manifested the presence of oral history in his work. I attempted to objectively prove (see: M. Kierzkowski, Oral history a najnowsza historia Polski. Wokót ksiązki Pawła Zyzaka, Lech Wałęsa. Idea $i$ historia. Biografia polityczna legendarnego przywódcy "Solidarności” do 1988 roku, [in:] Uwikłania historiografii. Między ideologizacja dziejów a obiektywizmem badawczym, ed. by T. Błaszczyk [et. al.], Poznań 2011, p. 123-132) - leaving aside the question of the fundamental error made in the sources, for instance in confusing credibility and authenticity of a source - the presence of oral history in Zyzak's work 
Therefore, a question arises - why is there very little attention devoted to oral history in schools? Firstly, future teachers very often do not have an opportunity to learn more about oral history during their studies. It is almost absent from the curricula of historical studies at universities even as a non-compulsory subject, not to mention teaching modules ${ }^{9}$. The uni

was only declarative. However, it is not possible to reach this conclusion on the basis of the opinions held by other participants of the discussion, like Sławomir Cenckiewicz (see: S. Cenckiewicz, Histeria zamiast lektury, http://www.rp.pl/artykul/285344. html, accessed December 1, 2015), Piotr Gontarczyk (see: P. Gontarczyk, Biografia nieodpowiedzialna, http://www.rp.pl/artykul/283737.html, accessed December 1, 2015), Jacek Żakowski (see: J. Żakowski, Powrót Galla Anonima, http://www.polityka. pl/tygodnikpolityka/kraj/287627,1,powrot-galla-anonima.read, accessed December 1, 2015) and Mirosław Czech (see: M. Czech, Biografia Watęsy. Prawicowe sikanie pod wiatr, http://wyborcza.pl/1,75515,6415763,Biografia_Walesy__Prawicowe_sikanie_ pod_wiatr.html, accessed December 1, 2015) who do not referre to the oral history in general but instead, to Paweł Zyzak's understanding of oral history which did not contribute to global reflection on the topic. This important remark nearly escaped the discussants' attention. Unfortunately, many claim that "practitioners of oral history still treat Zyzak's work as an example of a lack of reflection upon the method although the author did exactly what other historians would have done if they had been in his position. He simply used the selected accounts to portray a bigger picture of the past reality" (see: P. Wrona, Żywe źródło historyczne. Historia mówiona oczami historyka, [in:] Historia mówiona w świetle nauk humanistycznych i społecznych, ed. by S. Niebrzegowska-Bartmińska [et al.], Lublin 2014, p. 249). However, I believe that the author is not entitled to express an opinion on behalf of all historians. Moreover, I support all those who hold a view that regardless of the types of historical sources they cannot be treated as sources of truth. They are not the basis of a historian's work but only starting points (see: J. Topolski, Jak się pisze i rozumie historię. Tajemnice narracji historycznej, Poznań 2008, p. 279-290). In the case of oral history, it is vital to assume that working with oral accounts entails the need to interpret a source as some kind of cultural text which in turn means conducting various analyses, for instance the analyses of cultural patterns of remembering or recollecting memories as well as diversified narrative layers.

9 Non-compulsory classes on oral history were/are conducted at the University of Warsaw, the Jagiellonian University, Adam Mickiewicz University in Poznań, the Pontifical University of John Paul II in Kraków, the University of Warmia and Mazury in Olsztyn. Oral history is also one of the subjects conducted within the framework of Public History at the University of Wrocław. 
versity should be a place where students can get such knowledge ${ }^{10}$, but it's not commonly offered to them. For the same reason it is also absent from schools. Secondly, even if it finds its way to enter university and future teachers have an opportunity to hear about it, it still will be treated with reserve. It is because oral history is largely influenced by postmodern changes in science and is in opposition to what can be called "great modernistic historical narrative" which still dominates in educational system. Oral history is not such a type of narrative thus it is not present at schools. Thirdly, oral history is treated as some kind of intellectual fashion coming to Poland from the West and for this reason criticised and marginalised as a alien element which was not present in our historiographical tradition. Fourthly, there is a belief among teachers, resulting from the abovementioned arguments, that oral history itself is not "historical" enough. As a blend combining various elements like history, anthropology, sociology, psychology and many other disciplines, it is treated as a mixture which does not have its identity and definitely not a "historical" one. Therefore, it does not fit into the model of the present history education at schools. The same problem concerns those who deal with this unique hybrid. They represent various scientific, artistic, social and cultural communities which leads to the multiplication of discourses about the past which is inconvenient for multiplicity of historical narratives at schools.

Fortunately, the situation is slowly changing. There are more and more attempts at inviting oral history to Polish schools. These are usually external initiatives. Thanks to the simple and explanatory presentations of positive effects of this educational method in our neighbouring countries, especially the southern ones, the trust towards this basic model of establishing intergenerational bond is increasing.

\section{Oral history after all}

I would like to present below the increasing presence of oral history in history education at Polish schools as one of the ways in which teachers may engage their students in the process of learning. Several various actions are

10 See: M. Kierzkowski, Oral history - “Historia Badającego i Badanego". Uwagi o specyfice relacji ustnych $w$ kontekście badań historycznych, [in:] Obserwacja uczestniczaca w badaniach historycznych. Zbiór studiów, ed. by B. Wagner, T. Wiślicz, Zabrze 2008, p. 36. 
involved in it. I will focus on those which are supposed to be some form of support for teachers as well as on those which would directly engage students' imagination.

\section{Competitions}

One of the most basic methods of engaging and employing oral history in history education and schools is organising competitions which will stimulate students to pursue a unique quest for the signs of the past in the present time. The competitions are usually organised by external subjects and are addressed to the students from all over Poland. One of such competitions is a project "I will tell you about the free Poland" ("Opowiem Ci o wolnej Polsce") carried out since 2007 by the Centre of Civic Education (Centrum Edukacji Obywatelskiej), Polish Institute of National Remembrance (IPN) and the Warsaw Uprising Museum, involving organising meetings between students and witnesses of historical events. The organizers define the contest as follows:

The goal of the project is to familiarise students with the events from the recent history of Poland, showing how Polish civil society was shaped throughout the last decades. The key elements of the project are meetings and interviews with witnesses of historic events conducted by students. Young people have an opportunity to hear both familiar and less known stories, get to know the lives of those who actively participated in historical events, discover the history of a town or a region and feel the atmosphere of the past times. Students' task is to carry out interviews with those who actively participated in political and social life objecting to the political system in the years from 1939 to 1989. The meeting should be audio or videotaped and then described. Next young people pass the knowledge that they gained to others through organising exhibitions and performances and recording radio broadcasts. In this project students are very independent, they can make their own choices and express various ideas. It is hoped that the above-mentioned actions will contribute to shaping young people's identity, strengthening the bond with their places of birth and living and arousing patriotism and civic responsibility ${ }^{11}$.

11 http://www.ceo.org.pl/pl/opowiem-ci-o-wolnej-polsce/news/opis-programu (accessed December 1, 2015). 
The idea behind the competition is to gradually engage students in meticulous and inventive searching for the traces of the past in our reality. Students take part in the classes which aim is to prepare them for the meetings with witnesses to history, prepare questions concerning the historic event in which their interlocutors took part, then they carry out the interviews and finally they make a transcript of the whole or a part of the interview to later describe it or transform into a literary piece. Moreover, they collect documents - family photos, letters, prepare photographic documentation connected with people and events. All these actions are supposed to commemorate the past and propagate knowledge among local communities. Finally, each team needs to prepare a report on their project. The project lasts for nearly a year as it starts in August, when the recruitment process begins, to June, when the final conference is held. The teachers are also engaged in the project supporting the students and coordinating their work. E-coaching course which was introduced during the last edition of the project is addressed mainly to the teachers as the questions of selecting suitable teaching methods for the aim of the classes, potential advantages and disadvantages of the meetings or the issue of copyright are raised in it. Additionally, throughout the project and even after its realisation, teachers and students can make use of auxiliary materials and previous projects which are collected on a special website. Although the competition engages both teachers and students, the main goal of the project is for students to extend their knowledge about $2 \mathrm{O}^{\text {th }}$-century Poland, to acquire new competences connected with the technical aspect of oral history and most importantly to arouse their interest in local community and region and establish bonds with their cultural and intergenerational heritage.

Another competition called "Close History" ("Historia Bliska") has been organised regularly for 20 years. The event is an initiative of The KARTA Centre (Ośrodek KARTA) which is co-financed by Polish Ministry of Culture and National Heritage of the Republic of Poland and other institutions. So far there have been 18 editions of this competition, which has turned it into an independent institution with its well-developed website and patrons. The format of the competition and the main ideas behind it have not changed since its beginning and are as follows:

The projects are supposed to be about history which is "close" because of its time, place and relations. Thus it concerns the local history so the closest places, communities or people including the history of the so-called little homelands which is present in sources, testimonies or private documents. 
It is also about the facts from local history that are not familiar to larger groups of people, a story which hasn't got its narrator - perhaps some kind of mystery, important but forgotten event or achievement, unusual story - the history of war and peace, courage or conformity, victory or failure...

The topic may concern various spheres of life - everyday life, work, fight, social, religious, cultural, scientific and economic transformations, family and neighbour relations, those between the state and a citizen as well as relations between fellow countrymen and foreigners, their traces can be found in disputes about the past but also in the disputes about memorials, patrons or cemeteries ${ }^{12}$.

This competition has been attracting large groups of junior secondary school and secondary school students. Students can present their work in one of the possible formats - a film or an audio broadcast, a multimedia presentation or a text concerning important local issues in the $2 \mathrm{O}^{\text {th }}$-century Poland. Until today the topics were as follows: Daily life in Poland in the years 1944-1956; Citizen vs. the authorities in the years 1956-1980; The most important event in the history of my community. Witnesses and testimonies; Family in the $20^{\text {th }}$ century; Work in the times of the Polish People's Republic - for yourself, for the community or for the system?; Foreigners among fellow countrymen in the $20^{\text {th }}$ century; People in motion - migration, promotion, social degradation 1914-1989; Disputes about commemorating the past - memorials, cemeteries, patrons; Everyday life at the turn of 1944. and 1945; Religious life in the times of Polish People's Republic - individual, community, institution; The disobedient of the $20^{\text {th }}$ century; Little homeland in memory and testimonies; 1989 - end, turning point or beginning...?; Stigma of Second World War - fate and memory.

Regardless of the topic of the project, it is worth remembering that the starting point is always the willingness to find the other person who is close to us and to realize that he or she is also a part of this multi-narrative history. Thanks to employing oral history in education, our historical identity changes. History is no longer something unfamiliar, present only in school textbooks but it becomes a part of ourselves which is present in the memory of our family and friends.

12 http://historiabliska.pl/regulamin.php (accessed December 1, 2015). 
I have mentioned two contests with a long tradition and a countrywide recognition. However, there are also many actions which incorporate the use of oral history which are exclusively local in their character and they are in a way a result of the need to stimulate the community and propagate local identity. In this case I have selected two examples of projects which are the results of grass root initiatives and not external, top-down stimulation so they are not supposed to be universal in their territorial scope. This examples are among many local projects undertaken in the past few years.

The "Memory Hunters" ("Łowcy Pamięci") is carried out in Krotoszyn from 2014, originated by a local Janina Gwiżdż Society, Culture Centre in Krotoszyn and Hieronim Ławniczak Regional Museum in Krotoszyn. The project is divided into two parts. The first one involves collecting memories of the oldest inhabitants of Krotoszyn commune. Secondary and junior secondary school students together with their teachers are responsible for collecting memoirs and saving them on data carriers. Recorded stories usually consisted of the happiest and the most traumatic experiences connected with local history of the last decades. Later the accounts are used in the second part of the project, in preparing multimedia exhibition which is later presented on the market square in Krotoszyn as well as in the Museum in Krotoszyn (last such a presentation was in August and September 2015). As the organizers explain:

Our project takes place in the last possible moment to collect and preserve interviews with local "eyewitnesses to history". People who remember such historic periods like the pre-war years, World War II, or the post-war period pass away as the time goes by. We cannot make the mistake we made regarding the insurgents during the Greater Poland Uprising in 1918. Despite the technical possibilities we had, we didn't get any memoirs from that time. Such memoirs stored on electronic devices and later transcribed on that basis would be an impressive source of information about our town and region, especially from the point of view of ordinary inhabitants ${ }^{13}$.

The whole project which evolved from the idea of enriching and diversifying school education into something of a kind of intergenerational dialogue reinforcing the group identity was also appreciated by the local-

13 https:/web.facebook.com/LowcyPamieci/info/?tab=page_info (accessed December 1, 2015). 
-government in Krotoszyn, which considered the project "Łowcy pamięci"

to be "Best Local Initiative of 2014" in the field of culture and education.

The second project which, from my point of view, originated for similar reasons, is called "Traces of the Second World War locked in memoirs, monuments and roadside crosses", realized in 2005-2006 by pupils of the final year of primary school and the first year of secondary school from the Complex of Schools in Grabiny in the Podkarpackie region. The main subject of the project was clearly specified in time and space. It covered the years 1939-1945 and could be realized in the closest surroundings of the town. A starting point for the realization of the whole project was oral history:

The pupils had to prepare the list of people - eyewitnesses to history - with whom they would conduct interviews about the past. It was necessary to compile the list of places of the events that had been particularly influential for the history of Grabiny and the surrounding area. The collection of summaries from meetings and conversations, narratives of eyewitnesses and descriptions of places and events were published in "Księga wspomnień" ("Memoire book"). They also prepared a multimedia presentation and the album called "Zachować dla potomności" ("Preserve for the posterity") containing photographs (as well as illustrations) of the nearby places related with World War II $^{14}$.

Although the pupils were first heading towards the oldest members of their families to write down their memories from the bygone years, this attempt of building or renewing intergenerational relations existed also in the open public space. The purpose of the project involving the oral history or even basing on it was not to reconstruct the reality of life in the bygone era as in a historical reconstruction, or the answer to the question "how was it like at that time?" The aim was rather to fulfill the need of discovering in your life the roots of the previous generations, which would lead to an easier answer to the question "where did «today» come from?"

III Back up for teachers

Oral history, which allows teachers to engage pupils in an untypical performance within the school education, becomes a stronger and stronger tool for overcoming existing schemes. The mentioned competitions and

14 http://uczyc-sie-z-historii.pl/pl/projekty/lista-projektow/zobacz/62 (accessed December 1, 2015). 
projects are a proof for that. But it would not happen without teachers and their will to act. This is the reason why any projects helping teachers and showing them the way to accustom school education of history in Poland to oral history deserve particular attention. We should not forget about the fact that during the first stages of pedagogical preparation oral history still plays an insignificant role.

Fortunately, more and more of webpages and materials for teachers become available every year. The idea of providing educational packages for diversifying school education process is a very helpful thing. The packages usually accompany the final stages of various oral history projects. The packages prepared by the KARTA Centre and produced thanks to the financial support of the European Commission are worth mentioning. I am thinking here about the packages for the projects called "Kreuz-Krzyż w XX wieku. Polska i niemiecka pamięć pewnego miasta, Mauthausen-Gusen" ("Kreuz-Cross in the $20^{\text {th }}$ century. Polish and German memories about a certain town, Mauthausen-Gusen") and "Wrzesień 1939" ("September 1939"). Such packages include some interesting information in the form of index of fragments of memories, profiles of heroes, photographic documentation and complete lesson plans and are available on CDs. There is also a possibility of downloading them for free from the website ${ }^{15}$. The "Grodzka Gate - NN Theatre" Centre from Lublin prepared a similar project, proposing complete lesson plans containing memoirs and materials for teachers. They relate to the main themes raised by the Centre, such as Oral history of Lublin, Polish-Jewish town in the Lublin region; House, school and work - everyday life in Jewish Lublin; My little homeland; Social awareness of the image of Jews and Polish-Jewish relations on the basis of oral history of Lublin. The online materials are available as well ${ }^{16}$.

In my opinion, the best online platform in Polish on that issue is the webpage Uczyć się historii. Doświadczenie totalitaryzmów XX wieku (Learning history. The experience of totalitarianisms in the $20^{\text {th }}$ century), initiated and run by the KARTA Centre in collaboration with Polish and foreign partners. The description of the project says:

"Learning history" website - the project by KARTA Centre - is a platform for publication of educational projects dedicated to history of Poland 
and its neighbors in the $20^{\text {th }}$ century. Special emphasis is placed on the experience of the two totalitarian regimes: Nazism and communism in WWII, their heritage and contemporary debates about them as well as citizen education and human rights promotion.

The web site is addressed to teachers and other persons or institutions working with children and the youth. It intends to be a platform for exchange of opinions and deepening of knowledge, source of inspiration for work and studies as well as a laboratory for testing of the new methods of acquiring and exchanging knowledge about history ${ }^{17}$.

The website, which is divided into several sections, is the knowledge bank for teachers who want to include innovative ways of teaching during their lessons. At least 4 main sections of the webpage are really worth mentioning. First of all, the Projects section, with an index of all Polish projects which highlight the value of experience of self-directed history learning by pupils, and a need for using many possible solutions and tools that go beyond the foregoing standard notion of teaching history. One of these notions is of course oral history. The second interesting section (Articles) includes many inspiring texts about history for teachers and learners. There are subsections: dydaktyka (teaching), e-edukacja (e-education), historia (history), nauka (science), prawa czlowieka (human rights). The important fact is that the Article section is the one where teachers can share their experience and thoughts by sending their own texts. The third section, particularly interesting for me, is Materials, the place to provide downloads, which can be utilized by pupils and teachers for learning and teaching history, but not exclusively for them. Thanks to an interior filter dividing the content, there are subsections as well: Education, History, Methodology, and Sources. The last section, really valuable for teachers, is Linkownia (Links). This is a set of useful links of museums, memory places, funds, aid schemes, educational resources, archives, digital libraries, research institutes and historical-educational portals. In the end, it is worth mentioning that the webpage is an archive for materials from all the editions of the contest "Historia bliska" ("Close History").

The other virtual place, equally rich in content and interpretation possibilities, is "Świadkowie historii" ("Eyewitnesses to history") - an educational programme and a website, mainly for teachers, operated by Polish National

17 http://uczyc-sie-z-historii.pl/pl/o-nas (accessed December 1, 2015). 
Centre for Culture since $2008^{18}$. The original purpose was to gather, archive and share in an electronic form the narratives and memoirs of forgotten, silenced or unknown heroes of the modern history. A further initiative - and up to this time the only one - for teachers and educators of the "Eyewitnesses to history" project involved a publication entitled A book for oral history. Handbook, prepared by scholars: Marta Kurkowska-Budzan, Ewelina Szpak, Andrzej Drobik, Marcin Jarząbek and Marcin Stasiak. The project was aimed at practitioners of oral history and it treated and presented it as an element of releasing the history understood in the traditional way also in the educational system from the previous standards of historical knowledge and introducing it to the new standards. The book contains also a practical guidebook for preparing, conducting and evaluating the oral history project. The project "Eyewitnesses to history" itself changed its priorities over time. Now it focuses only on promoting oral history e.g. through creating a comprehensive database of entities dealing with the idea of gathering memories and oral narratives.

Eventually, I would like to mention the project "Archiwa społeczne"19 ("Community archives") originated thanks to the initiative of the KARTA Centre and financed by the National Audio-visual Institute and the Polish Ministry of Culture and National Heritage. This initiative provides an excellent database for history teachers, who include oral history in their lessons. The main purpose of this project is to create an independent grassroots archive movement, which would develop from many different associations, libraries and foundations, and which would form a network of community archives, which are being created.

[...] as an effect of the grassroots civic activity. Its main mission is an active work for saving and preserving the cultural heritage, and its purpose is to gather, preserve, develop and share materials of the non-government archive resources ${ }^{20}$.

The community archives understood as a part of the database of the website - there are already 450 such entities - gather various materials such as memoires, pictures, documents from everyday social and local life, and of course the recorded narratives. Therefore, they are a supplement

\footnotetext{
18 www.swiadkowiehistorii.pl (accessed December 1, 2015).

19 http://archiwa.org/index.php (accessed December 1, 2015).

20 http://archiwa.org/as_definicja.php (accessed December 1, 2015).
} 
of the deficiency of knowledge about history of everyday life of common people, which is insufficiently documented in many different state archive resources.

\section{Conclusions}

The presented overview of the possibilities and applications of oral history in Poland is only a trigger for further discussion. The role of oral history in the educational process in many countries in the world, and hopefully in Poland in the future as well, seems to fully justify the task I decided to take up. All the more so we still lack satisfactory analyses on the local market showing not only the potential of the presence of oral history at schools, but also the reason why it is essential, or even obvious that oral history should be taught at schools. Research conducted in Poland is mainly of practical form, similarly to the research in other countries. The theoretical look plays a secondary role or is of even lesser importance. The reality is that the researchers, instead of asking "how should we act, so that oral history could function as a fully-fledged form of the reflection about the past?" concentrate on the question "how can we benefit from oral history?" The lack of the theoretic look makes this method often the purposeless practice. It becomes a more or less reflective way of registering various stories without the awareness of the process of generating the historical source. I am far from the two extreme opposite attitudes, according to which we become either the supporters of the belief that it is necessary to assimilate all the knowledge about the topic to be able to go forward to the practical side of oral history, or we recklessly claim that the theory should wait until we are ensured that all living eyewitnesses to history are heard. Neither of these attitudes is comprehensible for me.

Going back to the existence of oral history in the process of education - both practical and theoretical aspect of history need to be taught simultaneously. We have lost too much time to postpone any of the mentioned activities, or to treat any of them of greater importance. Oral history in the process of education of history is a way for running away from the existing primate of the factual and event-related, as well as the monumental one, burdened with the legacy of two great totalitarianisms of the $20^{\text {th }}$ century. The oral history itself is a kind of a basis for building intergenerational relations, which are the ground for the sense of building the local community and the sense of its identity and integrity. This identity lets us discover all these little histories which make us more sensitive to other people. By taking a closer look at the past and learning it, one can better understand the present. 
Michat The article deals with an issue of the possible applications of oral his-

Kierzkowski

Oral history and historical education in

Poland. Possibilities and application tory to teaching history at Polish schools. The author states that oral history as an element of educating young people should become a natural part of teaching processes. It can become a factor increasing their awareness of their local history and of the links connecting them with the previous generations. It is also an efficient way of avoiding teaching based only on archival facts and events. This statement is illustrated by chosen examples of the use of oral history at schools and discusses the possibilities of its further use. 